\title{
Physiological and biochemical responses of a marine diatom Phaeodactylum tricornutum exposed to 1-octyl-3-methylimidazolium bromide
}

\author{
Xiang-Yuan Deng ${ }^{1,2, *}$, Jie Cheng ${ }^{1}$, Xiao-Li Hu${ }^{1}$, Kun Gao $^{1}$, Chang-Hai Wang ${ }^{2}$ \\ ${ }^{1}$ College of Biotechnology, Jiangsu University of Science and Technology, Zhenjiang 212003, PR China \\ ${ }^{2}$ Jiangsu Provincial Key Laboratory of Marine Biology, Nanjing Agricultural University, Nanjing 210095, PR China
}

\begin{abstract}
The marine diatom Phaeodactylum tricornutum is an important basal resource in the marine food chain and is used as a standard test organism in toxicological studies. In this study, in vivo experiments were performed to analyze the effects of 1-octyl-3-methylimidazolium bromide $\left(\left[\mathrm{C}_{8} \mathrm{mim}\right] \mathrm{Br}\right)$ on the growth, photosynthetic activity, and antioxidant enzymes of $P$. tricornutum using $96 \mathrm{~h}$ growth tests in a batch-culture system. The results showed that $\left[\mathrm{C}_{8} \mathrm{mim}\right] \mathrm{Br}$ significantly inhibited the growth of $P$. tricornutum, with a $96 \mathrm{~h} \mathrm{EC}_{50}$ of $8.89 \mathrm{mg} \mathrm{l}^{-1}$, and likely restricts PSII electron transfer and light use efficiency of the diatom. With increasing $\left[\mathrm{C}_{8} \mathrm{mim}\right] \mathrm{Br}$ concentrations, the soluble protein content in the diatom increased by 35.9, 58.5, 123.3, 197.7, and $207.0 \%$ in 5, 10, 20,40 , and $80 \mathrm{l}^{-1}\left[\mathrm{C}_{8} \mathrm{mim}\right] \mathrm{Br}$ treatments relative to the controls, respectively. Concentrations of $\left[\mathrm{C}_{8} \mathrm{mim}\right] \mathrm{Br} \leq 10 \mathrm{mg} \mathrm{l}^{-1}$ caused a slight increase of superoxide dismutase (SOD) activity (from 16.37 to $23.04 \mathrm{U} \mathrm{g}^{-1}$ protein) in the diatom, but inhibited its activity at concentrations above $10 \mathrm{mg} \mathrm{l}^{-1}$. These observations indicate that moderate $\left[\mathrm{C}_{8} \mathrm{mim}\right] \mathrm{Br}$ stress (about $10 \mathrm{mg} \mathrm{l}^{-1}$ ) likely stimulates the synthesis of proteins and free radical quenching. The general increase in malondialdehyde (MDA) content suggests that the physiological effects of $\left[\mathrm{C}_{8} \mathrm{mim}\right] \mathrm{Br}$ were caused by free radical generation. Thus, potential risks exist if $\left[\mathrm{C}_{8} \mathrm{mim}\right] \mathrm{Br}$ is accidentally released into the aquatic environment.
\end{abstract}

KEY WORDS: Ionic liquid · Phaeodactylum tricornutum • 1-octyl-3-methylimidazolium bromide · Photosynthetic activity $\cdot$ Antioxidant enzymes

\section{INTRODUCTION}

Ionic liquids (ILs), composed of a bulky organic cation and organic or inorganic anions, are environmentally friendly replacements for industrial volatile organic compounds because of their relatively low melting point (Pham et al. 2010). The main advantage of ILs is the significantly lower risk of industrial exposure and solvent loss to the environment. However, ILs are very stable and soluble in water (Bruzzone et al. 2011), which may potentially lead to water pollution and related risks once the ILs enter an aquatic environment (Latała et al. 2005, Zhao et al. 2007, Cho et al. 2008, Ventura et al. 2010, Cvjetko

*Corresponding author: dengxy2009@126.com
Bubalo et al. 2014). Recent studies have documented that ILs have toxic effects on aquatic organisms such as algae (Latała et al. 2009, 2010, Das \& Roy 2014), cladocerans (Couling et al. 2006, Luo et al. 2008, Pretti et al. 2009, Ventura et al. 2010), mussels (Costello et al. 2009), and fish (Pretti et al. 2009, Cvjetko Bubalo et al. 2014). The effects of ILs on aquatic organisms consist of 'alkyl side chain' effects (an increase in antimicrobial activity with the elongation of the alkyl chain) and the 'cut-off' effect (beyond a given chain length, the effects cannot increase any further) (Ventura et al. 2012).

Diatoms are important primary producers in aquatic ecosystems, contributing ca. $20-25 \%$ to

() The authors 2015. Open Access under Creative Commons by Attribution Licence. Use, distribution and reproduction are unrestricted. Authors and original publication must be credited. 
global primary productivity (Mann 1999, Montsant et al. 2005). Thus, diatoms have an important role in sustaining a healthy ecosystem. If they are adversely affected by a toxicant, the surrounding organisms may also be affected (either directly or indirectly) due to lack of food sources. Although some studies concerning the toxicity of ILs to diatoms have been reported (Latała et al. 2009, Ma et al. 2010, Samorì et al. 2011), to our knowledge, little work has been done regarding the toxic mechanism.

In this study, 1-octyl-3-methylimidazolium bromide ([ $\left.\left.\mathrm{C}_{8} \mathrm{mim}\right] \mathrm{Br}\right)$ was selected as the IL to be tested for the following reasons: (1) it is one of the representative imidazolium ILs (Luo et al. 2008, Yu et al. 2008, Ma et al. 2010, Li et al. 2012); (2) it is easily synthesized and widely used in the chemical industry (Bonhôte et al. 1996); (3) it has been commonly used in previous studies, with toxicity levels between that of [ $\left.\mathrm{C}_{6} \mathrm{mim}\right] \mathrm{Br}$ and $\left[\mathrm{C}_{10} \mathrm{mim}\right] \mathrm{Br}$ (Luo et al. 2008, Yu et al. 2008, Ma et al. 2010, Li et al. 2012). Our objectives were to evaluate the effects of $\left[\mathrm{C}_{8} \mathrm{mim}\right] \mathrm{Br}$ on the growth, photosynthetic activity, soluble protein content, antioxidant enzyme activity, and degree of lipid peroxidation on Phaeodactylum tricornutum. To our knowledge, this study is the first to report the toxic mechanism of imidazolium-based ILs on marine diatoms.

\section{MATERIALS AND METHODS}

\section{Test chemicals and solutions}

The IL [C $\left.{ }_{8} \mathrm{mim}\right] \mathrm{Br}$ (CAS number: 61545-99-1, purity $>99.9 \%$ ) was purchased from Chengjie Chemical; its chemical structure is shown in Fig. 1. Other chemicals used in this experiment were obtained from Sinopharm Chemical Reagent. Stock solutions were prepared in distilled water at a concentration of $5 \mathrm{~g}$ $\mathrm{l}^{-1}$. Test solutions were obtained by diluting the stock solution in f/2 medium (Guillard \& Ryther 1962). Concentrations used for the test solutions were 0,5 , $10,20,40$, and $80 \mathrm{mg} \mathrm{l}^{-1}$.

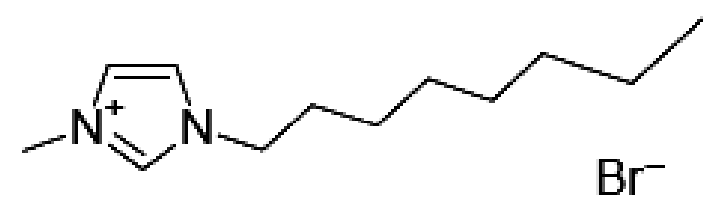

Fig. 1. Chemical structure of 1-octyl-3-methylimidazolium bromide $\left(\left[\mathrm{C}_{8} \mathrm{mim}\right] \mathrm{Br}\right)$

\section{Test organism}

The unicellular diatom Phaeodactylum tricornutum was obtained from the State Key Laboratory of Marine Environmental Science (Xiamen University), and grown photoautotrophically in $500 \mathrm{ml}$ Erlenmeyer flasks containing $200 \mathrm{ml}$ of $\mathrm{f} / 2$ medium. The inoculum was pre-cultured aseptically in $250 \mathrm{ml}$ Erlenmeyer flasks with $100 \mathrm{ml}$ of $\mathrm{f} / 2$ medium. The flasks were placed in a $20^{\circ} \mathrm{C}$ incubator (Jiangnan Instrument Factory), and illuminated from 2 sides by vertical cool white fluorescent lamps placed parallel to the flasks with a $12 \mathrm{~h}$ light:12 $\mathrm{h}$ dark photoperiod and a light density of $40 \mu \mathrm{mol}$ photons $\mathrm{m}^{-2} \mathrm{~s}^{-1}$.

\section{Experimental setup}

After pre-cultivation for $7 \mathrm{~d}$, the microalgal inoculum reached the exponential growth phase with a cell density of $2.2 \times 10^{7}$ cells $\mathrm{ml}^{-1}$. A total of $5 \mathrm{ml}$ of the microalgal inoculum was collected by centrifugation $\left(4000 \times g, 4^{\circ} \mathrm{C}, 15 \mathrm{~min}\right)$. The collected microalgal cells were washed twice with sterile seawater and then inoculated into the growth medium with an initial cell density of $1.1 \times 10^{6}$ cells $\mathrm{ml}^{-1}$.

In the growth inhibition experiments, cultures were grown in $250 \mathrm{ml}$ Erlenmeyer flasks containing $100 \mathrm{ml}$ of $\mathrm{f} / 2$ medium with different $\left[\mathrm{C}_{8} \mathrm{mim}\right] \mathrm{Br}$ concentrations $\left(0,5,10,20,40\right.$, and $\left.80 \mathrm{mg} \mathrm{l}^{-1}\right)$, each in triplicate. The cultivation conditions were as described above.

\section{Microalgal growth analysis}

Microalgal cell density was determined spectrophotometrically at $625 \mathrm{~nm}$ using a multi-mode microplate reader (SpectraMax M5; Molecular Devices). The relationship between microalgal cell density $\left(D\right.$, cells $\left.\mathrm{ml}^{-1}\right)$ and optical density of the microalgal culture at $625 \mathrm{~nm}\left(\mathrm{OD}_{625}\right)$ was determined experimentally, and is shown in the following equation:

$$
\begin{gathered}
D=\left(6.7685 \times \mathrm{OD}_{625}+0.0145\right) \times 10^{7}, \\
(\mathrm{R}=0.9897)
\end{gathered}
$$

The concentration for $50 \%$ of maximal effect $\left(\mathrm{EC}_{50}\right)$ values of $\left[\mathrm{C}_{8} \mathrm{mim}\right] \mathrm{Br}$ against $P$. tricornutum were determined using PASW Statistics 18 software (SPSS) according to Deng et al. (2012). 


\section{Measurements of photosynthetic parameters}

The photosynthetic parameters of $P$. tricornutum exposed to different $\left[\mathrm{C}_{8} \mathrm{mim}\right] \mathrm{Br}$ concentrations $(0,5$, $10,20,40$, and $\left.80 \mathrm{mg} \mathrm{l}^{-1}\right)$ at different times $(0,12,24,48$, 72 and 96 h) were measured by pulse-amplitude modulation (PAM) fluorometry (Phyto-PAM; Heinz Walz). Prior to measurements, samples were kept in the dark for $15 \mathrm{~min}$. Then, the maximum photochemical efficiency of photosystem II (PSII) $\left(F_{\mathrm{v}} / F_{\mathrm{m}}\right)$, potential activity of PSII $\left(F_{\mathrm{v}} / F_{0}\right)$, maximum relative electron transport rate $\left(\mathrm{rETR}_{\max }\right)$, and light use efficiency $(\alpha)$ were determined and calculated according to Schreiber (1998).

\section{Chlorophyll a concentration measurements}

To determine chlorophyll a (chl a) concentration, triplicates of $5 \mathrm{ml}$ well-blended cultures were centrifuged at $4000 \times g$ for $15 \mathrm{~min}$ to remove the supernatants. The pellets were then homogenized with $5 \mathrm{ml}$ of HPLC-grade methanol for pigment extraction. The mixtures were vigorously shaken with a Vortex and placed in a refrigerator in the dark at $4{ }^{\circ} \mathrm{C}$ for $24 \mathrm{~h}$. The methanol-extracted samples were then centrifuged at $10000 \times g$ for $5 \mathrm{~min}$ to remove the pellet, and the supernatants were transferred into 96-well plates (Corning Incorporated Life Sciences) and measured for chlorophyll at 750, 665, and $652 \mathrm{~nm}$ using a multimode microplate reader. All absorbance values were corrected using HPLC-grade methanol as a control. Concentrations of chl a were calculated following Porra (2002); to determine chl $a$ in $\mu \mathrm{g} \mathrm{ml}^{-1}\left(C_{a}\right)$ :

$$
C_{a}=16.29 \times\left(A_{665}-A_{750}\right)-8.54 \times\left(A_{652}-A_{750}\right)
$$

where $A_{652}, A_{665}$ and $A_{750}$ are the absorbance values at 652,665 and $750 \mathrm{~nm}$, respectively. The final value of chl a content was expressed as micrograms of chl a per $10^{7}$ cells $\left(\mu \mathrm{g} \times 10^{7} \mathrm{cell}^{-1}\right)\left(C^{\prime}{ }_{a}\right)$. This was calculated using:

$$
C^{\prime}{ }_{a}=\frac{C_{a} \times V_{\mathrm{MeOH}}}{D \times V_{\text {sample }}}
$$

where $V_{\mathrm{MeOH}}$ is the methanol volume $(5 \mathrm{ml}), V_{\text {sample }}$ is the volume of sample $(5 \mathrm{ml})$ and $D$ is the microalgal cell density (cells $\mathrm{ml}^{-1}$ ).

\section{Biochemical analysis}

Protein determination

After $96 \mathrm{~h}$ of [ $\left.\mathrm{C}_{8} \mathrm{mim}\right] \mathrm{Br}$ exposure, $40 \mathrm{ml}$ of wellblended cultures were harvested by centrifugation $\left(4000 \times g, 15 \mathrm{~min}, 4^{\circ} \mathrm{C}\right)$. The harvested microalgae were placed in $1.5 \mathrm{ml}$ of extraction buffer containing $0.05 \mathrm{M}$ sodium phosphate buffer ( $\mathrm{pH} 7.8$ ), and immediately lysed by sonication (Scientz Biotechnology) for 10 min with a repeating duty cycle of $5 \mathrm{~s}$ in an ice bath. The cellular homogenate was centrifuged at $12000 \times g$ for $10 \mathrm{~min}$ at $4^{\circ} \mathrm{C}$, and the liquid supernatant was stored at $-70^{\circ} \mathrm{C}$ for protein determination and enzyme assay.

Total soluble protein content was measured using the Bradford method with bovine serum albumin as standard (Bradford 1976). Results were expressed as micrograms of protein per $10^{7}$ cells $\left(\mu \mathrm{g} \times 10^{7} \mathrm{cell}^{-1}\right)$.

\section{Superoxide dismutase and malondialdehyde determination}

Superoxide dismutase (SOD) and malondialdehyde (MDA) assay kits were purchased from Jiancheng Bioengineering Institute. SOD and MDA were extracted and determined from the supernatant liquids (above) according to the manufacturer's instructions and Wang \& Zheng (2008). The results of SOD activity and MDA content are given as units of enzyme activity per microgram of total soluble protein $\left(\mathrm{U} \mathrm{g}^{-1}\right.$ protein) and nanomole per $10^{7}$ cells (nmol $\left.10^{7} \mathrm{cell}^{-1}\right)$, respectively.

\section{Statistical analysis}

All results are presented as mean \pm SD. Statistical analysis was performed using PASW Statistics 18 software. A 1-way ANOVA was used to establish differences among treatments, with a significance level set at $\alpha=5 \%$.

\section{RESULTS AND DISCUSSION}

\section{Growth of Phaeodactylum tricornutum after exposure to $\left[\mathrm{C}_{8} \mathrm{mim}\right] \mathrm{Br}$}

The effects of $\left[\mathrm{C}_{8} \mathrm{mim}\right] \mathrm{Br}$ on cell density and growth of $P$. tricornutum are shown in Fig. 2. Although $P$. tricornutum presented positive growth in all $\left[\mathrm{C}_{8} \mathrm{mim}\right] \mathrm{Br}$ treatments, the cell densities in 5, $10,20,40$, and $80 \mathrm{mg} \mathrm{l}^{-1}\left[\mathrm{C}_{8} \mathrm{mim}\right] \mathrm{Br}$ treatments were $64.1,49.5,43.4,25.8$, and $24.0 \%$ of that in the controls after $96 \mathrm{~h}$ exposure, respectively. Growth inhibition also increased with increasing exposure time from 0 to $96 \mathrm{~h}$ (e.g. an increase in growth inhibition 


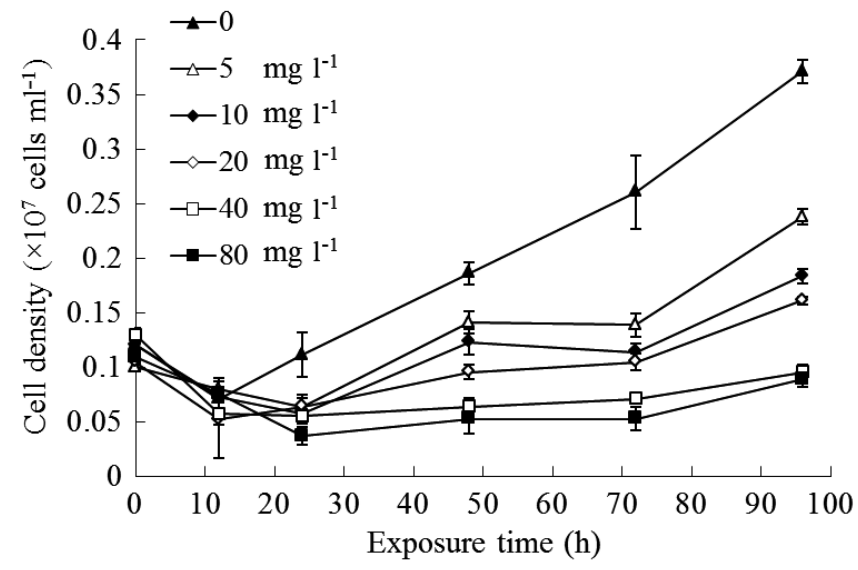

Fig. 2. Growth curves of Phaeodactylum tricornutum under different $\left[\mathrm{C}_{8} \mathrm{mim}\right] \mathrm{Br}$ concentrations $\left(0\right.$ to $80 \mathrm{mg} \mathrm{l}^{-1}$ ) during $96 \mathrm{~h}$ exposure. Points: means of 3 replicates; error bars: SD

from 0 to $76.0 \%$ in $80 \mathrm{mg} \mathrm{l}^{-1}\left[\mathrm{C}_{8} \mathrm{mim}\right] \mathrm{Br}$ treatments) and increasing $\left[\mathrm{C}_{8} \mathrm{mim}\right] \mathrm{Br}$ concentration from 5 to $80 \mathrm{mg} \mathrm{l}^{-1}$ (e.g. an incremental growth inhibition from 35.9 to $76.0 \%$ at $96 \mathrm{~h}$ exposure). A similar phenomenon has also been described for Scenedesmus obliquus after treatment with $\left[\mathrm{C}_{8} \mathrm{mim}\right] \mathrm{Br}$ (Ma et al. 2010). Our results were easily visible due to the color change of the microalgal cells from brown to white (Fig. 3). Therefore, we conclude that potential risks do exist if $\left[\mathrm{C}_{8} \mathrm{mim}\right] \mathrm{Br}$ is accidentally released into the aquatic environment.

In this study, the $\mathrm{EC}_{50}$ values of $\left[\mathrm{C}_{8} \mathrm{mim}\right] \mathrm{Br}$ against $P$. tricornutum were determined and calculated by Marquardt's algorithm method (Deng et al. 2012), and our results compared to data on $\left[\mathrm{C}_{8} \mathrm{mim}\right] \mathrm{Br}$ toxicity to microalgae in previously published literature (Table 1).The differences in $\mathrm{EC}_{50}$ values - spanning several orders of magnitudebetween algal taxa may help to explain the mechanism of IL toxicity (Kulacki \& Lamberti 2008, Samorì et al. 2011). One clue to this mechanism may be related to the cell wall structures of different microalgal species, since the cell wall plays an important role in the transport of materials in and out of the cell (Kulacki \& Lamberti 2008, Samorì et al. 2011). However, additional studies are required in order to fully investigate the effect of these cell wall structural differences, particularly with respect to IL toxicity.

\section{Photosynthetic activity of $\boldsymbol{P}$. tricornutum after exposure to $\left[\mathrm{C}_{8} \mathrm{mim}\right] \mathrm{Br}$}

The changes in photosynthetic activity of $P$. tricornutum exposed to $\left[\mathrm{C}_{8} \mathrm{mim}\right] \mathrm{Br}$ are shown in Fig. 4. After $24 \mathrm{~h}$ exposure, $F_{\mathrm{v}} / F_{\mathrm{m}}$ and $F_{\mathrm{v}} / F_{0}$ showed no significant differences at $\left[\mathrm{C}_{8} \mathrm{mim}\right] \mathrm{Br}$ concentrations of $\leq 20 \mathrm{mg} \mathrm{l}^{-1}(\mathrm{p}>0.05)$, but there were slight decreases $(73.8$ and $65.6 \%$ of that in controls, respectively) in the $40 \mathrm{mg} \mathrm{l}^{-1}$ treatments, and a sharp decrease (27.6 and $18.2 \%$, respectively) in the $80 \mathrm{mg}$ $\mathrm{l}^{-1}$ treatments. However, in the controls, $F_{\mathrm{v}} / F_{\mathrm{m}}$ and $F_{\mathrm{v}} / F_{0}$ increased sharply from 24 to $48 \mathrm{~h}$ exposure, and then remained constant (about 0.56 and 1.32, respectively) after $48 \mathrm{~h}$ exposure. The $F_{\mathrm{v}} / F_{\mathrm{m}}$ and $F_{\mathrm{v}} / F_{0}$ in the $5,10,20,40$, and $80 \mathrm{mg} \mathrm{l}^{-1}$ treatments were 88.1, $75.4,70.7,51.1,17.6 \%$, and 72.9, 54.1, 48.8, 29.9, $7.6 \%$ that of the controls after $96 \mathrm{~h}$ exposure, respec-

Table 1. Comparison of the toxicity of $\left[\mathrm{C}_{8} \mathrm{mim}\right] \mathrm{Br}$ to microalgae. $\mathrm{EC}_{50}$ : concentration for $50 \%$ of maximal effect; nr: not reported

\begin{tabular}{|lccl|}
\hline Microalgae & $\begin{array}{c}\text { Duration } \\
(\mathrm{h})\end{array}$ & $\begin{array}{c}\mathrm{EC}_{50} \\
\left(\mathrm{mg} \mathrm{l}^{-1}\right)\end{array}$ & Reference \\
\hline Freshwater species & & & \\
Chlamydomonas reinhardtii & 96 & 50.69 & Kulacki \& Lamberti (2008) \\
Chlorella ellipsoidea & 96 & 6.37 & Ma et al. (2010) \\
Selenastrum capricornutum & 96 & $7.24-15.11$ & Cho et al. (2007) \\
Scenedesmus obliquus & 96 & 0.34 & Ma et al. (2010) \\
Scenedesmus quadricauda & 96 & 0.005 & Kulacki \& Lamberti (2008) \\
Marine species & & & \\
Phaeodactylum tricornutum & 96 & 8.89 & This study \\
Oocystis submarina & 288 & $\mathrm{nr}$ & Latała et al. (2005) \\
Cyclotella meneghiniana & 288 & $\mathrm{nr}$ & Latała et al. (2005) \\
& & & \\
\hline
\end{tabular}

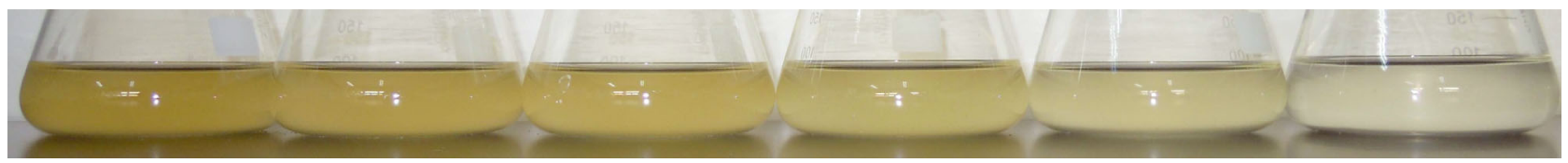

Fig. 3. Change in morphology of Phaeodactylum tricornutum with different $\left[\mathrm{C}_{8} \mathrm{mim}\right] \mathrm{Br}$ treatments: from left to right: control, 5 , $10,20,40$, and $80 \mathrm{mg} \mathrm{l}^{-1}$ 

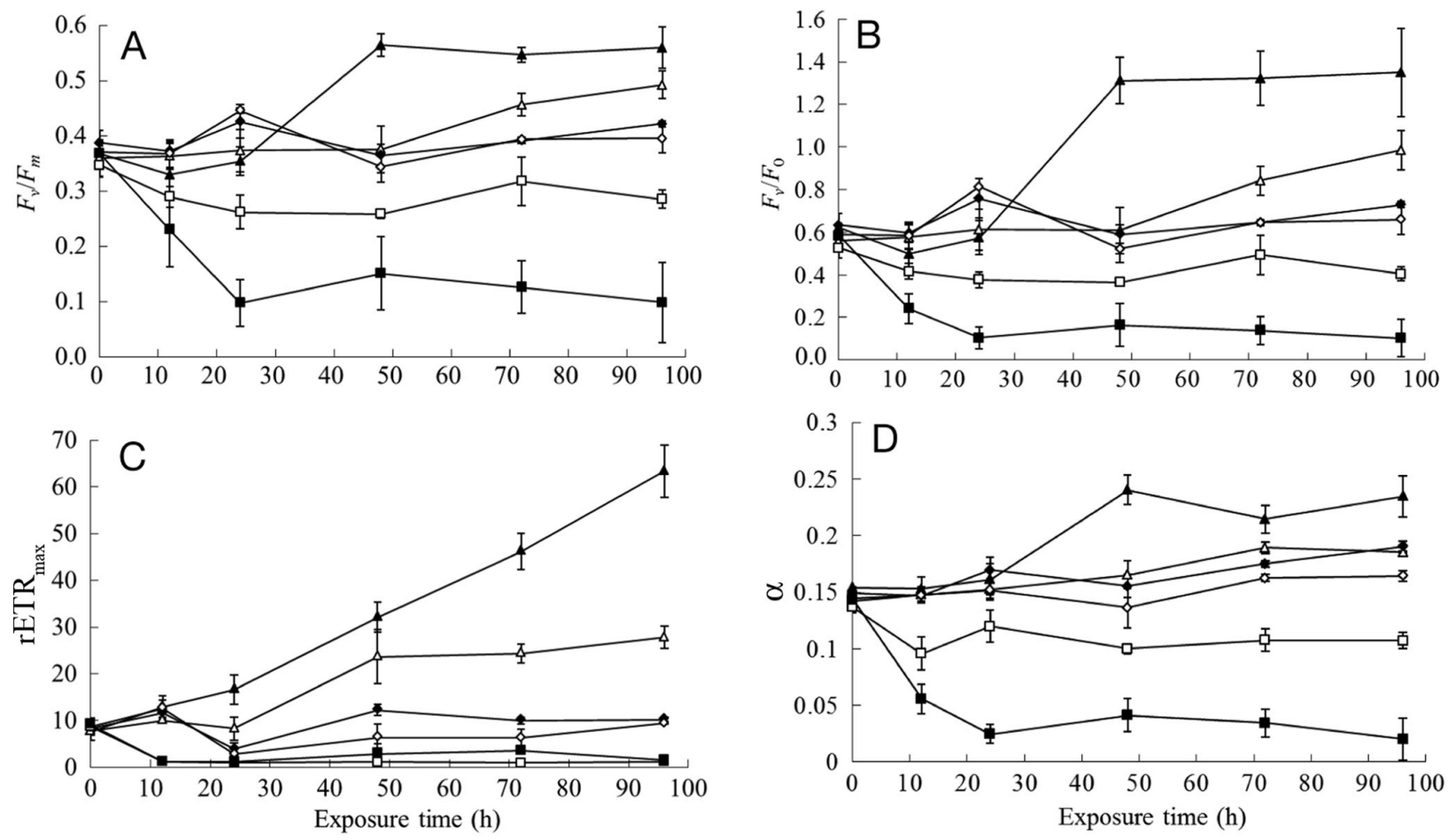

$\rightarrow 0 \mathrm{mg} \mathrm{l}^{-1} \rightarrow-5 \mathrm{mg} \mathrm{l}^{-1} \rightarrow-10 \mathrm{mg} \mathrm{l}^{-1}$

$\leadsto-20 \mathrm{mg} \mathrm{l}^{-1}-\square-40 \mathrm{mg} \mathrm{l}^{-1} \rightarrow-80 \mathrm{mg} \mathrm{l}^{-1}$

Fig. 4. Photosynthetic activity changes in Phaeodactylum tricornutum under different levels of $\left[\mathrm{C}_{8} \mathrm{mim}\right] \mathrm{Br}$ stress during $96 \mathrm{~h}$ of exposure, showing changes in (A) maximum photochemical efficiency of PSII $\left(F_{\mathrm{v}} / F_{\mathrm{m}}\right),(\mathrm{B})$ potential activity of PSII $\left(F_{\mathrm{v}} / F_{0}\right),(\mathrm{C})$ maximum relative electron transport rate $\left(\mathrm{rETR}_{\max }\right)$, and $(\mathrm{D})$ light use efficiency $(\alpha)$. Points: means of 3 replicates; error bars: SD

tively (Fig. $4 \mathrm{~A}, \mathrm{~B}$ ). This reduction in $F_{\mathrm{v}} / F_{\mathrm{m}}$ and $F_{\mathrm{v}} / F_{0}$ may lead to a decrease in conversion efficiency of primary light energy. Another photosynthetic parameter, rETR, mainly reflects the electron transport status of the PSII reaction center (Kitajima \& Butler 1975). Fig. $4 \mathrm{C}$ shows that $\mathrm{rETR}_{\max }$ increased sharply from 7.7 to 63.4 in the controls after $96 \mathrm{~h}$ cultivation, but there were almost no increases in any of the $\left[\mathrm{C}_{8} \mathrm{mim}\right] \mathrm{Br}$ treatments. The $\mathrm{rETR}_{\max }$ decreased by $56.2,83.8,85.2,98.0$, and $97.6 \%$ in $5,10,20,40$, and $80 \mathrm{mg} \mathrm{l}^{-1}\left[\mathrm{C}_{8} \mathrm{mim}\right] \mathrm{Br}$ treatments relative to the controls at $96 \mathrm{~h}$ exposure, respectively. Reduction of $\mathrm{rETR}_{\max }$ indicates that the photosynthetic electron transfer of $P$. tricornutum was hindered by $\left[\mathrm{C}_{8} \mathrm{mim}\right] \mathrm{Br}$. In addition, $\alpha$ (representing light use efficiency) was not significantly different in $\left[\mathrm{C}_{8} \mathrm{mim}\right] \mathrm{Br}$ treatments of $\leq 20 \mathrm{mg} \mathrm{l}^{-1}$ before $24 \mathrm{~h}$ exposure $(\mathrm{p}>0.05)$. But in the 40 and $80 \mathrm{mg} \mathrm{l}^{-1}$ $\left[\mathrm{C}_{8} \mathrm{mim}\right] \mathrm{Br}$ treatments, there were decreases to 74.4 and $15.3 \%$ of that in the controls, respectively, at $24 \mathrm{~h}$ exposure. At that point, $\alpha$ increased in the controls and remained constant in the $\left[\mathrm{C}_{8} \mathrm{mim}\right] \mathrm{Br}$ treatments after $48 \mathrm{~h}$ exposure. At $96 \mathrm{~h}$ exposure, the $\alpha$ decreased by $21.0,18.8,30.0,54.3$, and $91.3 \%$ in 5 , $10,20,40$, and $80 \mathrm{mg} \mathrm{l}^{-1}\left[\mathrm{C}_{8} \mathrm{mim}\right] \mathrm{Br}$ treatments rela- tive to the controls, respectively (Fig. 4D). Thus, we conclude that $\left[\mathrm{C}_{8} \mathrm{mim}\right] \mathrm{Br}$ likely hinders photosynthetic electron transfer and restrict light use efficiency leading to growth inhibition.

\section{Chlorophyll in P. tricornutum after exposure to $\left[\mathrm{C}_{8} \mathrm{mim}\right] \mathrm{Br}$}

As antenna pigments, chlorophyll can transfer photons to the reaction center (P680) in PSII of microalgae, and this change will affect the microalgal photosynthetic activity (Kalaji \& Guo 2008). The change in chl $a$ in $P$. tricornutum under $\left[\mathrm{C}_{8} \mathrm{mim}\right] \mathrm{Br}$ stress is illustrated in Fig. 5. It shows that chl a concentrations did not change significantly in $\left[\mathrm{C}_{8} \mathrm{mim}\right] \mathrm{Br}$ treatments of $\leq 20 \mathrm{mg} \mathrm{l}^{-1}$ ( $\left.\mathrm{p}>0.05\right)$, but a marked decrease ( 44.9 and $41.2 \%$ of that in the controls) was observed in the treatments with 40 and $80 \mathrm{mg} \mathrm{l}^{-1}$ $\left[\mathrm{C}_{8} \mathrm{mim}\right] \mathrm{Br}$, respectively. According to Couling et al. (2006), the alkyl chain possessed by $\left[\mathrm{C}_{8} \mathrm{mim}\right] \mathrm{Br}$ may be incorporated into the polar head groups of the phospholipid bilayer, which would result in the disruption of membrane-bound proteins and the structural integrality of chloroplasts. 


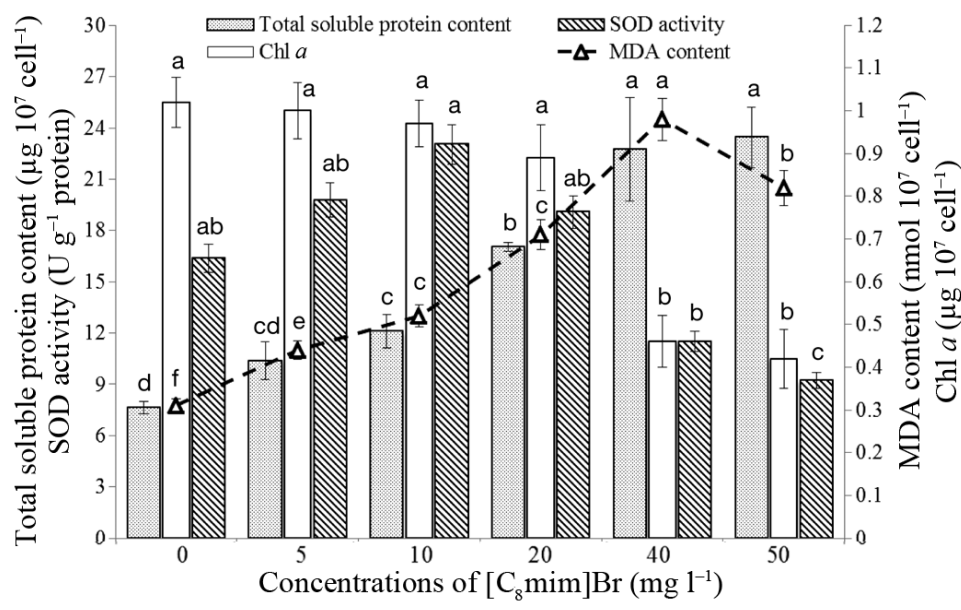

Fig. 5. Mean $( \pm S D)$ values $(n=3)$ of chl a content, total soluble protein content, superoxide dismutase (SOD) activity and malondialdehyde (MDA) content in Phaeodactylum tricornutum after $96 \mathrm{~h}$ of exposure to different levels of $\left[\mathrm{C}_{8} \mathrm{mim}\right] \mathrm{Br}$. Points: means of 3 replicates; error bars: $\mathrm{SD}_{\text {; }}$ different lowercase letters: datasets that are significantly different from each other $(p<0.05)$
When microalgae are exposed to various abiotic stresses, ROS production increases in the microalgal cells. Lipid peroxidation often occurs in microalgal cells when ROS is excessive, and an end-product of lipid peroxidation (i.e. MDA) is detected (Apel \& Hirt 2004). In this study, MDA content in the diatom significantly increased by 40.0, 66.1, 129.7, and $215.7 \%$ with increasing $\left[\mathrm{C}_{8} \mathrm{mim}\right] \mathrm{Br}$ concentrations from 5 to $40 \mathrm{mg} \mathrm{l}^{-1}$. The maximum MDA content $\left(0.98 \mathrm{nmol} 10^{7} \mathrm{cell}^{-1}\right)$ was obtained in $40 \mathrm{mg} \mathrm{l}^{-1}\left[\mathrm{C}_{8} \mathrm{mim}\right] \mathrm{Br}$ treatments (Fig. 5). But the MDA content decreased to $0.82 \mathrm{nmol} 10^{7} \mathrm{cell}^{-1}$ in the diatom exposed to $80 \mathrm{mg} \mathrm{l}^{-1}\left[\mathrm{C}_{8} \mathrm{mim}\right] \mathrm{Br}$ (Fig. 5). We infer that free radicals such as ROS were generated in the diatom under $\left[\mathrm{C}_{8} \mathrm{mim}\right] \mathrm{Br}$ stress, which gave rise to MDA. More MDA would damage the diatom cells because MDA may readily interact with several functional groups of molecules, such as proteins, lipoproteins, and DNA (Maes et al. 2006).

\section{Soluble protein content, SOD activity and MDA content of $P$. tricornutum after exposure to $\left[\mathrm{C}_{8} \mathrm{mim}\right] \mathrm{Br}$}

Fig. 5 shows that soluble protein content increased by $35.9,58.5,123.3,197.7$, and $207.0 \%$ in the 5,10 , 20,40 , and $80 \mathrm{mg} \mathrm{l}^{-1}\left[\mathrm{C}_{8} \mathrm{mim}\right] \mathrm{Br}$ treatments relative to the controls, respectively. Enzymes, including antioxidant and biotransformation enzymes, are important components in soluble proteins, and may serve as an active defense mechanism to protect cells from $\left[\mathrm{C}_{8} \mathrm{mim}\right] \mathrm{Br}$ stress (Kumar et al. 2008). Thus, we suggest that $\left[\mathrm{C}_{8} \mathrm{mim}\right] \mathrm{Br}$ could increase soluble protein synthesis in the diatom cells.

SOD is the most important enzyme in reactive oxygen species (ROS) scavenging, and can catalyze the dismutation of the highly reactive superoxide anion to $\mathrm{H}_{2} \mathrm{O}_{2}$ (Blokhina et al. 2003). In the present study, $\left[\mathrm{C}_{8} \mathrm{mim}\right] \mathrm{Br}$ concentrations $\leq 10 \mathrm{mg} \mathrm{l}^{-1}$ caused a slight increase (from 16.37 to $23.04 \mathrm{U} \mathrm{g}^{-1}$ protein) in SOD activity in the diatoms, with the maximum SOD activity of $23.04 \mathrm{U} \mathrm{g}^{-1}$ protein obtained in the $10 \mathrm{mg} \mathrm{l}^{-1}\left[\mathrm{C}_{8} \mathrm{mim}\right] \mathrm{Br}$ treatments (Fig. 5). SOD activity may also be enhanced in different organisms following exposure to IL stresses (Yu et al. 2009, Li et al. 2012, Zhang et al. 2013). However, SOD activity in the diatom decreased from 23.04 to $9.24 \mathrm{U} \mathrm{g}^{-1}$ protein when $\left[\mathrm{C}_{8} \mathrm{mim}\right] \mathrm{Br}$ concentrations increased from 10 to $80 \mathrm{mg} \mathrm{l}^{-1}$ (Fig. 5). The inactivation of antioxidant enzymes may result in high lipid peroxidation and low photosynthetic pigments, thereby inhibiting microalgal cell growth.

\section{CONCLUSIONS}

This is the first report on the toxic mechanism of $\left[\mathrm{C}_{8} \mathrm{mim}\right] \mathrm{Br}$ on a marine diatom. In this study, the growth of Phaeodactylum tricornutum was significantly inhibited by $\left[\mathrm{C}_{8} \mathrm{mim}\right] \mathrm{Br}$, which inhibited the chlorophyll synthesis, hindered photosynthetic electron transfer and restricted light use efficiency of this diatom. Simultaneously, remarkable physiological and biochemical responses were observed in the diatom. The increase of protein content and SOD activity at low concentrations may be viewed as an active defense against moderate $\left[\mathrm{C}_{8} \mathrm{mim}\right] \mathrm{Br}$ stress by free radical quenching. The general increase in MDA level suggests that physiological effects of $\left[\mathrm{C}_{8} \mathrm{mim}\right] \mathrm{Br}$ were likely caused by free radical generation.

Acknowledgements. The manuscript was supported by the National Natural Science Foundation of China (No. 31200381), China Postdoctoral Science Foundation funded project (No. 2013M531370, 2014T70532), Key Laboratory for Ecological Environment in Coastal Areas, State Oceanic Administration (201209).

\section{LITERATURE CITED}

Apel K, Hirt H (2004) Reactive oxygen species: metabolism, oxidative stress, and signal transduction. Annu Rev Plant Biol 55:373-399

Blokhina O, Virolainen E, Fagerstedt KV (2003) Antioxidants, oxidative damage and oxygen deprivation stress: a review. Ann Bot 91:179-194 
Bonhôte P, Dias AP, Papageorgiou N (1996) Hydrophobic, highly conductive ambient-temperature molten salts. Inorg Chem 35:1168-1178

Bradford MM (1976) A rapid and sensitive method for the quantitation of microgram quantities of protein utilizing the principle of protein-dye binding. Anal Biochem 72: 248-254

Bruzzone S, Chiappe C, Focardi SE, Pretti C, Renzi M (2011) Theoretical descriptor for the correlation of aquatic toxicity of ionic liquids by quantitative structure-toxicity relationships. Chem Eng J 175:17-23

> Cho CW, Pham TPT, Jeon YC, Vijayaraghavan K, Choe WS, Yun YS (2007) Toxicity of imidazolium salt with anion bromide to a phytoplankton Selenastrum capricornutum: effect of alkyl-chain length. Chemosphere 69:1003-1007

> Cho CW, Jeon YC, Pham TPT, Vijayaraghavan K, Yun YS (2008) The ecotoxicity of ionic liquids and traditional organic solvents on microalga Selenastrum capricornutum. Ecotoxicol Environ Saf 71:166-171

Costello DM, Brown LM, Lamberti GA (2009) Acute toxic effects of ionic liquids on zebra mussel (Dreissena polymorpha) survival and feeding. Green Chem 11:548-553

Couling DJ, Bernot RJ, Docherty KM, Dixon JK, Maginn EJ (2006) Assessing the factors responsible for ionic liquid toxicity to aquatic organisms via quantitative structureproperty relationship modeling. Green Chem 8:82-90

> Cvjetko Bubalo M, Radošević K, Radojčić Redovniković I, Halambek J, Srćek VG (2014) A brief overview of the potential environmental hazards of ionic liquids. Ecotoxicol Environ Saf 99:1-12

> Das RN, Roy K (2014) Predictive modeling studies for the ecotoxicity of ionic liquids towards the green algae Scenedesmus vacuolatus. Chemosphere 104:170-176

> Deng XY, Gao K, Sun JL (2012) Physiological and biochemical responses of Synechococcus sp. PCC7942 to Irgarol 1051 and diuron. Aquat Toxicol 122-123:113-119

Guillard RRL, Ryther JH (1962) Studies of marine planktonic diatoms. I. Cyclotella nana Hustedt, and Detonula confervacea (Cleve) Gran. Can J Microbiol 8:229-239

Kalaji MH, Guo PG (2008) Chlorophyll fluorescence: a useful tool in barley plant breeding programs. In: Sanchez A, Gutierrez SJ (eds) Photochemistry research progress. Nova Science Publishers, New York, NY, p 439-463

Kitajima M, Butler WL (1975) Quenching of chlorophyll fluorescence and primary photochemistry in chloroplasts by dibromothymoquinone. Biochim Biophys Acta 376: 105-115

Kulacki KJ, Lamberti GA (2008) Toxicity of imidazolium ionic liquids to freshwater algae. Green Chem 10:104-110

Kumar S, Habib K, Fatma T (2008) Endosulfan induced biochemical changes in nitrogen-fixing cyanobacteria. Sci Total Environ 403:130-138

Latała A, Stepnowski P, N dzi M, Mrozik W (2005) Marine toxicity assessment of imidazolium ionic liquids: acute effects on the Baltic algae Oocystis submarina and Cyclotella meneghiniana. Aquat Toxicol 73:91-98

Latała A, N dzi M, Stepnowski P (2009) Toxicity of imidazolium and pyridinium based ionic liquids towards algae. Bacillaria paxillifer (a microphytobenthic diatom) and Geitlerinema amphibium (a microphytobenthic blue green alga). Green Chem 11:1371-1376

Latała A, N dzi M, Stepnowski P (2010) Toxicity of imidazolium ionic liquids towards algae. Influence of salinity variations. Green Chem 12:60-64

Li XY, Zeng SH, Dong XY, Ma JG, Wang JJ (2012) Acute

Editorial responsibility: Kedong Yin,

Brisbane, Queensland, Australia toxicity and responses of antioxidant systems to 1methyl-3-octylimidazolium bromide at different developmental stages of goldfish. Ecotoxicology 21:253-259

Luo YR, Li XY, Chen XX, Zhang BJ, Sun ZJ, Wang JJ (2008) The developmental toxicity of 1-methyl-3-octylimidazolium bromide on Daphnia magna. Environ Toxicol 23: 736-744

Ma JM, Cai LL, Zhang BJ, Hu LW, Li XY, Wang JJ (2010) Acute toxicity and effects of 1-alkyl-3-methylimidazolium bromide ionic liquids on green algae. Ecotoxicol Environ Saf 73:1465-1469

Maes M, Mihaylova I, Leunis JC (2006) Chronic fatigue syndrome is accompanied by an IgM-related immune response directed against neopitopes formed by oxidative or nitrosative damage to lipids and proteins. Neuroendocrinol Lett 27:615-621

Mann DG (1999) The species concept in diatoms. Phycologia 38:437-495

Montsant A, Jabbari K, Maheswari U, Bowler C (2005) Comparative genomics of the pennate diatom Phaeodactylum tricornutum. Plant Physiol 137:500-513

> Pham TPT, Cho CW, Yun YS (2010) Environmental fate and toxicity of ionic liquids: a review. Water Res 44:352-372

Porra RJ (2002) The chequered history of the development and use of simultaneous equations for the accurate determination of chlorophylls $a$ and $b$. Photosynth Res 73: 149-156

Pretti C, Chiappe C, Baldetti I, Brunini S, Monni G, Intorre L (2009) Acute toxicity of ionic liquids for three freshwater organisms: Pseudokirchneriella subcapitata, Daphnia magna and Danio rerio. Ecotoxicol Environ Saf 72: 1170-1176

> Samorì C, Sciutto G, Pezzolesi L, Galletti P and others (2011) Effects of imidazolium ionic liquids on growth, photosynthetic efficiency, and cellular components of the diatoms Skeletonema marinoi and Phaeodactylum tricornutum. Chem Res Toxicol 24:392-401

Schreiber U (1998) Chlorophyll fluorescence: new instruments for special applications. In: Garab G (ed) Photosynthesis: mechanisms and effects. Kluwer Academic Publishers, Dordrecht, p 4253-4258

- Ventura SP, Goncalves AMM, Goncalves F, Coutinho JA (2010) Assessing the toxicity on $\left[\mathrm{C}_{3} \mathrm{mim}\right][\mathrm{Tf} 2 \mathrm{~N}]$ to aquatic organisms of different trophic levels. Aquat Toxicol 96: 290-297

Ventura SP, de Barros RLF, Sintra T, Soares CMF, Lima AS, Coutinho JAP (2012) Simple screening method to identify toxic/non-toxic ionic liquids: agar diffusion test adaptation. Ecotoxicol Environ Saf 83:55-62

Wang LP, Zheng BH (2008) Toxic effects of fluoranthene and copper on marine diatom Phaeodactylum tricornutum. J Environ Sci 20:1363-1372

Yu M, Li SM, Li XY, Zhang BJ, Wang JJ (2008) Acute effects of 1-octyl-3-methylimidazolium bromide ionic liquid on the antioxidant enzyme system of mouse liver. Ecotoxicol Environ Saf 71:903-908

Yu M, Wang SH, Luo YR, Han YW, Li XY, Zhang BJ, Wang JJ (2009) Effects of the 1-alkyl-3-methylimidazolium bromide ionic liquids on the antioxidant defense system of Daphnia magna. Ecotoxicol Environ Saf 72:1798-1804

> Zhang BJ, Li XY, Chen DD, Wang JJ (2013) Effects of 1octyl-3-methylimidazolium bromide on the antioxidant system of Lemna minor. Protoplasma 250:103-110

Zhao DB, Liao YC, Zhang ZD (2007) Toxicity of ionic liquids. CLEAN-Soil, Air, Water 35:42-48

Submitted: May 20, 2015; Accepted: November 4, 2015

Proofs received from author(s): November 27, 2015 